\title{
Cor e hierarquia social no Brasil escravista: o caso do Paraná, passagem do século XVIII para o XIX
}

\author{
Cacilda Machado
}

"No Brasil, ninguém é puro. E é por isso que o Brasil tem a cara do futuro". Assim se pronunciou o professor de Harvard Henry Louis Gates Jr, em uma entrevista, ${ }^{1}$ a propósito do alto grau de miscigenação da população brasileira, característica tradicionalmente destacada nos mais importantes estudos de história e sociologia, e que recentemente foi confirmada nas pesquisas do professor Sergio Danilo Pena, da Universidade Federal de Minas Gerais. Esse geneticista encontrou altos índices de ancestralidade africana ou ameríndia na população brasileira considerada "branca", bem como altos índices de ancestralidade europeia e ameríndia na população considerada "negra". ${ }^{2}$

Nos EUA, a pesquisa coordenada pelo professor Gates Jr também acusou esses resultados, em mais baixo grau, no entanto. Ele mesmo sugere uma explicação ao afirmar que, por muito tempo, as uniōes entre negros e brancos sofreram sanções nos EUA, embora continuasse havendo mistura, enquanto no Brasil tais uniões ocorreram mais livremente. Também na reportagem, o geneticista Sérgio Danilo Pena corrobora a tese e acrescenta que, no Brasil, tradicionalmente, os filhos nascidos de uniōes entre negros e brancos, se forem de pele clara, são considerados e tratados como brancos. Já nos EUA é irrelevante a cor da pele, eles serão sempre negros. Em outras palavras, Sergio Danilo Pena defende uma ideia já antiga, a de que o processo de racialização das relações sociais não vingou no Brasil, e até por isso comumente as pessoas se autoidentificam e identificam o outro mais pela cor da pele do que pela origem.

As pesquisas desses geneticistas também esclarecem aspectos relativos à história do processo de miscigenação no Brasil e nos EUA. Ainda na entrevista citada, somos informados que nos dois países os exames do cromossomo Y, que indica a linhagem paterna, mostraram grande componente europeu, enquanto a linhagem materna aparece bem mais diversificada entre europeias, africanas e indígenas. A explicação, segundo Gates, é que nos dois países era comum que os colonizadores mantivessem relacionamentos sexuais - frequentemente forçados - com escravas ou mulheres indígenas.

Esta é uma tese compartilhada por alguns cientistas sociais e por ativistas do movimento negro brasileiro, mas não pela maioria. Análises recentes têm descoberto que a miscigenação também foi, em grande parte, resultado de relacionamentos consensuais entre portugueses pobres e mulheres negras e indígenas. "A riqueza aparta as pessoas, mas a pobreza une. Havia pelo Brasil, muitos portugueses pobres, aventureiros que vinham tentar a vida aqui. A miscigenação que existe hoje é também resultado dessa história de pobres amantes". ${ }^{3}$

Tais palavras são esclarecedoras porque sugerem que as relações entre escravos e livres e entre brancos e negros, no Brasil, foram muito mais complexas do que indica a tese que vincula de forma direta miscigenação à violência sexual. Isso porque, como já ressaltou Rebecca Scott, por exemplo, em função do efeito cumulativo das manumissões, nas diferentes áreas do Brasil eram estreitos os laços entre livres e escravos. E se era rara a identidade política e de cor entre brancos ricos e brancos pobres, o caráter extensivo da propriedade de escravos entre os pobres também criava tensões que dividiam livres e cativos. ${ }^{4}$

Assim, pois, se deve considerar que as histórias do Brasil e dos Estados Unidos se distinguem não apenas em função das diferenças de intensidade da miscigenação. Há também, pode-se dizer, diferenças na periodização e nas características do processo de emancipação nos dois países. Como se sabe, à época de suas respectivas aboliçóes, Brasil e EUA apresentavam um quadro populacional completamente diverso: em 1860 havia mais de 4.000.000 de cativos nos EUA; no Brasil eles eram pouco mais de 
720.000 em 1887. Além disso, no Brasil, em 1872, as pessoas livres de cor representavam cerca de 45\% da população total e $74 \%$ do total da população de cor, sendo que o componente mulato do total da população de cor havia chegado a 66\%, quadro em todo diverso dos EUA, onde, às vésperas da Guerra Civil, em 1860, os negros livres compreendiam apenas $11 \%$ da população não branca total. ${ }^{5}$

Em "Memórias do cativeiro", Ana Lugão Rios e Hebe Mattos indicam que o tema das relações raciais nas Américas é questão antiga. No entanto, "durante muitos anos considerou-se mais ou menos a mesma coisa estudar as relações raciais no pós-abolição ou o destino das populações libertas, considerando ambas as situações uma herança do período escravista" . ${ }^{6}$ Nesse sentido, a abolição "se apresentaria quase como um não-fenômeno, incapaz de gerar mudanças". 7 A "construção do pós-abolição como um problema” é, segundo as autoras, fruto de um conjunto de pesquisas recentes nas várias regiōes das Américas. Essas pesquisas

permitiram reavaliar também os estudos históricos sobre relaçōes raciais e a ideia de "herança da escravidão". Para tanto, o ponto de partida foi a percepção de que a construção das identidades raciais negras nas Américas não se fez como contrapartida direta da violência intrínseca à ordem escravista. Trata-se de reconhecer que o processo de destruição da escravidão moderna esteve visceralmente imbricado com o processo de definição e extensão dos direitos de cidadania nos novos países que surgiam das antigas colônias escravistas. E que, por sua vez, a definiçáo e o alcance desses direitos estiveram diretamente relacionados com uma contínua produção social de identidades, hierarquias e categorias raciais. Nesse sentido, a historicidade das identidades e classificaçóes raciais tornou-se questão central para o entendimento dos processos de emancipação escrava e das formas como as populaçóes afrodescendentes e as sociedades pós-emancipação lidaram culturalmente com os significados da memória do cativeiro. ${ }^{8}$

Creio que têm razão as autoras, porém, considerando que, além do alto grau de miscigenação, as alforrias foram fenômenos recorrentes ao longo de todo o período escravista e especialmente no século XIX - e portanto cada vez mais numerosa a população de negros e mestiços forros e livres -, no Brasil $a$ produção social de identidades, hierarquias e categorias raciais teve inicio muito antes da abolição. De fato, em Sobrados \& Mocambos, Gilberto Freyre já indicava que o século XIX foi um período de intensificação de fenômenos já presentes durante toda a época colonial, como as alforrias e a miscigenação, ou seja, de enorme alargamento da população livre de cor, e declínio da população escrava. ${ }^{9}$

De certa forma, se pode considerar que no Brasil a produção social do "servo", do "administrado" e do "liberto" ou "forro" foi concomitante à produção social do "escravo" e do "livre"; a produção social do "mulato" e do "pardo foi concomitante a do "branco" e do "negro". Enfim, entre nós o aprendizado da liberdade foi concomitante e não posterior à escravidão. Tendo isso em vista, pode-se pressupor que são distintos não apenas a historicidade das identidades e classificaçôes raciais do Brasil e dos Estados Unidos, como também o são os processos de emancipação escrava e das formas como as populaçôes afrodescendentes (e ameríndias, eu acrescentaria) e as sociedades pós-emancipação lidaram culturalmente com os significados da memória do cativeiro.

Os pesquisadores em geral concordam que, por sua subjetividade, o uso social da cor, no Brasil, foi em grande medida um fenômeno tributário do esforço de produzir diferenças no interior do grande grupo de indivíduos que não eram escravos/negros ou livres/brancos. Ademais, esse caráter subjetivo da cor também se adequava bem a uma sociedade na qual o trânsito social de cada um se definia no âmbito das relações interpessoais. Não por acaso, boa parte daqueles que estudam escravidão e relações raciais no Brasil sugerem que no país a cor constituía (e ainda constitui) categoria sociológica extremamente complexa, conformada a partir de inúmeras variáveis.

Porém, há que se atentar que mesmo no interior da América portuguesa, dependendo da época e da região, esse processo apresentou variadas faces. Com vistas a contribuir para a discussão desse aspecto, no presente artigo exponho alguns dados e considerações acerca da relação entre cor e hierarquia social no Brasil escravista a partir do caso paranaense, região que na passagem do século XVIII para o XIX, isto é, em plena vigência da escravidão e de expansão do tráfico atlântico de africanos, apresentava um baixo percentual de população escrava e um alto contingente de livres de cor. 


\section{O espaço socioeconômico paranaense}

Ainda que a maior parte do território meridional do Brasil fosse, desde o século XVI, reivindicada pelos espanhóis, a historiografia desde sempre registra serem aquelas terras, por então, sistematicamente percorridas também por outros europeus, especialmente por portugueses organizados em expediçôes exploradoras e preadoras. Contudo, a ocupação portuguesa tornou-se mais efetiva somente a partir de 1570-1580, quando foram encontrados os primeiros vestígios de faíscas de ouro no litoral paranaense. Desde então, populações provenientes de Cananeia, São Vicente, Santos, São Paulo e Rio de Janeiro começaram a estabelecer sítios na região, utilizando o trabalho de índios - do litoral ou apresados no interior - e, mais tarde, também de negros escravizados.

A primeira povoação foi Paranaguá, originada em 1617 e elevada à categoria de vila em 1649. Em 1656, Paranaguá se tornou centro da então recém-criada Capitania de Nossa Senhora do Rosário de Paranaguá - subordinada ao Rio de Janeiro. Ao longo do século XVII manteve-se o interesse pelo ouro e, em sua busca, os mineradores ultrapassaram a Serra do Mar, atingindo as terras altas do interior. Ali, a cata de ouro desenvolveu-se por todo o Planalto de Curitiba chegando a atingir a vasta regiáo do Assungui, Jaguariaiva e do Tibagi. ${ }^{10}$ A partir do inicio do XVIII o ouro das Minas Gerais eclipsou a modesta produção paranaense, que no entanto existiu pelo menos até meados do século XVIII. Em 1711 a capitania passou à condição de comarca da então recém-criada Capitania de São Paulo, e em 1735 a casa de fundição de Paranaguá foi definitivamente fechada. ${ }^{11}$

Em busca do ouro, no planalto os mineradores formaram alguns núcleos populacionais, que mais tarde se transformaram em vilas e freguesias. Dois deles deram origem às povoaçôes de Nossa Senhora da Luz dos Pinhais (Curitiba) - freguesia de Paranaguá desde 1654, distrito desde 1660, e finalmente elevada à categoria de vila em 1693 - e São José e Bom Jesus dos Perdões (São José dos Pinhais), freguesia ligada a Curitiba em 1757, mas cujo inicio do povoamento data de fins do século XVII, e foi anterior mesmo ao de Curitiba.

Mesmo antes do declínio da economia aurífera, já se desenvolvia alguma agricultura e pecuária na região. À medida que se exauria o ouro, contudo, os moradores intensificaram a produção de alimentos, a criação de gado, e envolveram-se mais no tropeirismo, atividades que rapidamente se vincularam à economia do Centro-sul, em face da grande demanda por alimentos em Minas Gerais. No século XVIII, o alto preço do gado nas Minas contribuiu para a multiplicação das fazendas de criação e de invernagem, especialmente após 1730, quando da abertura do Caminho do Viamão, que ligava o Continente do Sul a Sorocaba, passando necessariamente pelo Paraná. Esse caminho propiciou a formação de novas povoações no planalto, como Itararé, Jaguariaiva, Piraí, Iapó (Castro), Carrapatos, Santa Cruz (Ponta Grossa), Lapa, Palmeira etc., que eram primitivamente lugares de pouso e currais de descanso ou invernadas de gado. ${ }^{12}$

$\mathrm{Na}$ verdade, a atividade criatória e o comércio com Sorocaba existiam mesmo antes da abertura do Caminho do Viamão. ${ }^{13}$ Quando percorreu a região meridional da colônia, entre 1719 e 1721, para correicionar as povoações, o Ouvidor Rafael Pires Pardinho escreveu que as duas freguesias de Curitiba, a de Nossa Senhora da Luz, a principal, e a de São José e Bom Jesus dos Perdōes, tinham suas populações distribuídas por um perímetro de até sete léguas, em geral vivendo da criação de "gado vacum", que era levado para a feira de Sorocaba, enquanto alguns ainda exploravam ouro de lavagem nos contrafortes da serra. ${ }^{14} \mathrm{Na}$ mesma carta ao Rei de Portugal, o ouvidor Pardinho indicava as potencialidades econômicas do planalto:

Dizem aquelles moradores [de Curitiba], que tem penetrado o sertão para o Poente, que todo he de Campos com seos capões, e restingas de mattos, com boas aguas, e ferteis para curraes, e criaçóes nos quaes se poderão fazer grandes fazendas se para elles se alargarem os gados: que o gentio he mui pouco por elle porque apenas se achão algûs pequenos lotes. Os mesmos campos vão correndo pelo pé dos mattos da Serra de Pernampiacaba; e algûs dizem ser facil abrir para elles caminho da Villa de Laguna, donde se lhe podem introdusir gados, que se condusam, e tragão pelas praias do Rio grande de São Pedro, com que brevemente se estabelecerão neles grandes fazendas de currais. ${ }^{15}$ 
Pardinho se referia aos Campos Gerais, que ao longo do XVIII e do XIX se tornou a mais importante área paranaense de criação e de invernagem dos animais comprados no Rio Grande do Sul, e revendidos em Sorocaba. A atividade criatória também incentivou a colonização dos sertões mais a oeste, território há muito disputado por portugueses e espanhóis. Em 1809, Diogo Pinto de Azevedo Portugal chefiou a primeira bandeira povoadora dos Campos de Guarapuava, ${ }^{16}$ descobertos e explorados no século XVIII por grupos de sertanistas. Anos mais tarde, uma expedição chefiada por Francisco Martins Lustosa chegou aos Campos de Guarapuava, e atrás da desembocadura do Rio Iguaçu acabou descobrindo os Campos de Palmas. ${ }^{17}$

De um modo geral, se pode afirmar que coexistiam, nas terras do Planalto do Paraná, nas primeiras décadas do século XIX, três formas distintas de povoamento - ainda que oriundas de um mesmo movimento: a dos Campos de Curitiba, onde a população consolidava a pequena propriedade, quase sempre apossamentos, desenvolvendo o comércio interno; a dos Campos Gerais, onde a existência de grandes fazendas contribuiu para o comércio exportador em grande escala, configurado pela criação de gado e as invernadas; por fim a integração dos Campos de Guarapuava (e depois os Campos de Palmas) para a ampliação dos rebanhos. ${ }^{18}$

A historiografia tradicionalmente descreve as grandes fazendas dos campos do Paraná como propriedades autossuficientes, produzindo o necessário para sua alimentação, vestuário, mobiliário, instrumentos de trabalho, material para a construção das casas, entre outros. Além dos proprietários e seus parentes, nelas viviam indivíduos e famílias de agregados, foreiros, fazendeiros e assistentes, estes últimos responsáveis pela comercialização dos produtos das fazendas que assistiam, principalmente junto aos pousos. ${ }^{19}$ Podiam ser brancos pobres, mas também libertos e livres de cor (descendentes de africanos e/ou ameríndios), por vezes ocupados nas funções de capatazes, feitores, capangas e vigilantes. Alguns tinham sítios, onde criavam cavalos e vacas, plantavam milho e feijão, e negociavam suas pequenas produções com os tropeiros que vinham do Sul. ${ }^{20}$

Os grandes proprietários dos Campos Gerais eram geralmente senhores de escravarias maiores dos que os das terras curitibanas. O tropeiro José Felix da Silva, por exemplo, um dos mais importantes da região campeira, em 1817 possuía 92 cativos divididos em três fazendas, o que dá uma média de 30 escravos por unidade produtiva. ${ }^{21}$ Existiam africanos entre os cativos, mas estes eram principalmente crioulos. Além disso, no século XVIII e mesmo no principio do XIX, ainda que em menor número, também era possível encontrar cativos de origem indígena. ${ }^{22}$ No entanto, mesmo os grandes senhores dos Campos Gerais tinham escravarias mais modestas do que as comumente encontradas nas regióes agroexportadores do $\mathrm{Su}$ deste brasileiro, pois, de uma maneira geral, a pecuária exigia poucos braços. Octavio Ianni, por exemplo, calculou que 3 a 4 mil cabeças de gado podiam ser cuidadas por 4 a 6 peóes liderados por um capataz. ${ }^{23}$

Nos sítios, quase sempre a família estava diretamente empenhada no trabalho da terra (plantavase geralmente milho, trigo, feijão e mandioca, mas também fumo, linho, árvores frutíferas etc.). As propriedades localizadas nos caminhos tornaram-se unidades de sustentação dos tropeiros e militares; aquelas próximas às vilas dedicavam-se ao abastecimento das populações urbanas. ${ }^{24}$

Na região de Curitiba, a paisagem agrária compunha-se, principalmente, de sítios agrícolas, e de quando em quando uma fazenda, em geral menor e com menos escravos e agregados do que as dos Campos Gerais. No século XVIII, parte da produção regional seguia para São Paulo pelo Caminho do Viamão, ou era exportada pelo porto de Paranaguá - principalmente para o Rio de Janeiro, Salvador e Santos. Também por Paranaguá, os habitantes do planalto tinham acesso a vinhos, panos de lá, linho e algodão, sal, louças, vinagre, açúcar e outros artigos, oriundos daqueles mesmos portos, e também de Lisboa. ${ }^{25}$

O dinamismo econômico do planalto paranaense na passagem do século XVIII para o XIX pode ser avaliado pela riqueza das fazendas dos Campos Gerais, pelo movimento de expansão em direção aos Campos de Guarapuava e Palmas, pelo intenso comércio entre o planalto e o litoral e especialmente ao longo do Caminho do Viamão. Não por acaso, na segunda metade do século XVIII Curitiba disputou com Paranaguá a hegemonia econômica e política local, até que em 1812 tornou-se sede da Comarca. Em 1822, Curitiba era a segunda maior vila da capitania paulista (11.867 habitantes), atrás apenas de São Paulo (24.311), sendo maior do que Sorocaba (8.908) e Itu (8.247) ${ }^{26}$ 


\section{As origens da mão-de-obra servil}

Ao descrever o ambiente demográfico e cultural do Rio de Janeiro no início do século XIX, José Roberto Góes se refere à série de relatos de viajantes espantados e perturbados com a "prodigiosa quantidade de negros", "enxame de negros", "turba agitada de negros" que obstruía as ruas da cidade. Tais impressōes, inclusive, sugeriram ao autor a ideia da produção de uma África no Brasil, expressão que dá título ao item em que trata do assunto, ${ }^{27}$ e que tão bem sintetiza a história da constituição da população e da mão-de-obra escrava no Rio de Janeiro colonial. Retrato um tanto diverso, todavia, daquele que se poderia traçar para a região paranaense, assim como para boa parte da capitania de São Paulo.

Em Negros da Terra, ${ }^{28}$ John Monteiro realizou um estudo da constituição, reprodução e declínio da escravidão indígena em São Paulo nos séculos XVI e XVII. Nesta obra, o apresamento e o usufruto do trabalho dos índios revela o propósito maior da aventura bandeirante, até então comumente caracterizada, pela historiografia, por sua dimensão geopolítica, na qual o índio - quando mencionado - "desempenha um papel apenas secundário e efêmero, ocupando a antessala de um edifício maior onde reside a escravidão africana". ${ }^{29}$ Para John Monteiro,

as frequentes incursões ao interior, em vez de abastecerem um suposto mercado de escravos índios no litoral, alimentavam uma crescente força de trabalho indígena no planalto, possibilitando a produção e o transporte de excedentes agrícolas; assim, articulava-se a região da chamada Serra Acima a outras partes da colônia portuguesa e mesmo ao circuito mercantil do Atlântico meridional. ${ }^{30}$

O autor chega mesmo a afirmar que se podem situar as origens da escravidão no Brasil nesta fase inicial das relações luso-indígenas. ${ }^{31}$ Nesse sentido, destaco não apenas esta noção de que um fenômeno relativamente concentrado num espaço e num tempo determinados pudesse ter tal reverberação, mas em especial sua preciosa ideia de que a escravidão brasileira não foi uma instituição exógena aqui estabelecida, mas sobretudo um aprendizado, o produto histórico de uma multiplicidade de relaçôes culturais e políticas. Nas palavras do pesquisador,

das diversas formas de exploração ensaiadas, nenhuma delas resultou satisfatória e, igualmente, todas tiveram um impacto negativo sobre as sociedades indígenas, contribuindo para a desorganização social e o declínio demográfico dos povos nativos. Como consequência, os colonizadores voltaram-se cada vez mais para a opção do trabalho forçado na tentativa de construir uma base para a economia e sociedade colonial. ${ }^{32}$

Desse processo resultou, a partir do final do século XVII, a Administração Particular, um arranjo institucional que permitiu a manutenção e a reprodução de relações escravistas, a despeito da resistência indígena e da legislação contrária ao trabalho forçado dos povos nativos. Como administradores particulares dos índios - considerados incapazes de administrarem a si mesmos -, "os colonos produziram um artifício no qual se apropriaram do direito de exercer pleno controle sobre a pessoa e propriedade dos mesmos sem que isso fosse caracterizado juridicamente como escravidão", ${ }^{33}$ embora não impedisse que os administrados fossem arrolados em inventários e entrassem nas partilhas, ou que fossem vendidos.

No Paraná, cuja colonização é parte da história da expansão paulista, desde o inicio da ocupação do litoral e do planalto ocorriam entradas de cativos africanos. No entanto, os carijós do litoral e os coroados do planalto estavam mais à mão, e exigiam menores investimentos para serem transformados em escravos. Embora em seus Provimentos, em 1721, o ouvidor Pardinho insistisse no fim da prática, comum entre os moradores da região, de escravizar índios, ${ }^{34} \mathrm{em}$ torno de 1736 as autoridades reconheciam explicitamente a necessidade de utilização de escravos indígenas na mineração em Curitiba. Da mesma forma, em 1745 um regimento estabelecia que aqueles indígenas "tomados em guerras justas" poderiam ser escravizados, pois Portugal sabia que os administrados eram o esteio da economia da parte meridional da colônia. ${ }^{35}$ Para se ter uma ideia da importância dessa mão-de-obra na região, vale lembrar os números encontrados por Schwartz, em seu estudo sobre compadrio de escravos em Curitiba. 
Esse autor menciona que entre 1685 e 1709 era irrelevante o número de negros batizados na vila, e que só em 1740 africanos e afro-brasileiros batizados finalmente excederam em número aos índios. ${ }^{36}$

Chegaram africanos ao Paraná ao menos até 1855, em geral pelo porto de Paranaguá. Contudo, acredita-se que o mais comum era a aquisição de escravos negros nos principais centros de comércio de gado por onde passavam os tropeiros dos Campos Gerais e dos Campos de Curitiba. Isso teria propiciado a conformação de uma população negra cativa majoritariamente crioula. ${ }^{37}$

Desde os primórdios da colonização, portanto, a mão-de-obra servil do Paraná era formada tanto pelos "administrados" indígenas, como por africanos ou crioulos. Nesse contexto, cativos de origens e histórias muito heterogêneas eram reunidos num mesmo plantel, passando a conviver cotidianamente, respondendo a um mesmo senhor, dividindo as tarefas da labuta diária. Exemplo disso encontra-se no testamento aberto em 1722, de Isabel Fernandes da Rocha, moradora de São José dos Pinhais. Nele foram declarados dezoito "servos",

a saber inferiores de velhice Balthazar, Breutis escrava, [ileg.], Severina, Rufina Pascoa, todos carijós, pessoas de serviço, Anna mollata escrava, Lourenço mollato, Manoel mina, Antonio Tobe mina, Esmeria carijó; duas raparigas de dez annos de idade pouco mais ou menos por nome Barbara, mollata, Narciza, carijó, dous rapazes de campanha de sete para oito annos chamados [cor.+-3 pal.] Outro de idade de seis annos chamado Salvador, duas crianças mollatas por nome Angela e Clara escravas, mas hum rapas chamado João escravo. ${ }^{38}$

Um outro exemplo, dos muitos que eu poderia citar, está registrado na Lista Geral de Habitantes da Freguesia de São José dos Pinhais de 1782, quando foram recenseados 152 escravos e 28 administrados - e ressalto que por então o uso do termo "administrado" denotava uma desatualização em relação à lei, já que após 1755, tanto os índios que já estavam libertos como os que eram administrados foram considerados forros, por ter sido extinta a instituição da administração particular. ${ }^{39}$

Esta mescla se manteve por muito tempo, pois no Paraná o "costume" de apresar e escravizar índios foi garantido ao menos até o princípio do século XIX. Em uma carta régia expedida ao governador e capitão general de São Paulo em 1808, Dom João VI fala de suas preocupações diante "do quase total abandono em que se acham os Campos Gerais de Curitiba e os de Guarapuava, infestados pelos índios que atacam fazendeiros e proprietários". Diante disso o rei determina "que todo o miliciano, ou qualquer morador que segurar alguns índios poderá considerá-los por quinze anos como prisioneiros de guerra, destinando-os ao serviço que mais lhe convier" ${ }^{40}$ No ano seguinte, outra carta régia, relativa à organização de uma expedição para a conquista dos Campos de Guarapuava, autorizava o cativeiro dos aborígines, por "quinze anos contados desde o dia em que foram batizados". ${ }^{41}$

\section{Os escravos do Paraná na passagem do século XVIII para o XIX}

A ausência de estatísticas torna difícil a tarefa de estimar o peso percentual da população escrava no Paraná do século XVIII. Octavio Ianni escreveu que em meados daquele século teria ocorrido o apogeu do regime escravocrata na região. O autor cita a estimativa do Capitão-general de São Paulo, Dom Luis Antonio de Souza Botelho e Mourão (o Morgado de Mateus), que em 1767 calculou em 50\% a proporção de escravos entre os habitantes da região. Esse número parece exagerado, e o próprio Ianni não confiou na contagem, deduzindo que o Morgado de Mateus teria considerado todos os negros, índios e mestiços como escravos. Ianni indica, ainda, que no último quartel do XVIII, certamente teve início um decréscimo acentuado da população cativa, e credita isso ao fato de, desde então, a expansão econômica da área se efetuar em um ritmo mais lento, e à queda da participação relativa do grupo devido ao crescimento vegetativo maior dos livres. ${ }^{42}$ 
Tabela 1 - Participação (absoluta e relativa) da população escrava no Paraná - Séculos XVIII e XIX

\begin{tabular}{|c|c|c|c|}
\hline AnOs & Escravos & $\%$ & TOTAL DA POPULAÇÃO \\
\hline 1772 & 1.712 & $22,4 \%$ & 7.627 \\
\hline 1798 & 4.273 & 20,3 & 20.999 \\
\hline 1804 & 5.077 & 19,3 & 26.370 \\
\hline 1810 & 5.135 & 18,6 & 27.589 \\
\hline 1816 & 5.010 & 17,6 & 28.470 \\
\hline 1824 & 5.855 & 17,8 & 32.887 \\
\hline 1830 & 6.260 & 17,1 & 36.701 \\
\hline 1836 & 7.873 & 18,4 & 42.890 \\
\hline 1854 & 10.189 & 16,4 & 62.258 \\
\hline 1858 & 8.493 & 12.2 & 69.380 \\
\hline 1868 & 10.000 & 10,0 & 100.000 \\
\hline 1874 & 11.249 & 8,8 & 127.411 \\
\hline
\end{tabular}

Fontes: Dados para o ano de 1772: WESTPHALEN, Cecília. Verbete freguesia de São José dos Pinhais. Dicionário Histórico Biográfico do Estado do Paraná. Curitiba: Editora Livraria do Chain/BANESTADO, 1991, p. 180. Para os anos entre 1798 e 1830: COSTA, Iraci \& GUTIÉRREZ, Horácio. Paraná. Mapas de População 17981830. São Paulo: IPE/USP, 1985, passim. Dados de 1836 a 1874: PENA, Eduardo Spiller. O Jogo da Face: a astúcia escrava frente aos senhores è̀ lei na Curitiba provincial. Curitiba: Aos Quatro Ventos, 1999, p.29.

Os dados são mais confiáveis a partir do final do XVIII. Na tabela 1 é possível acompanhar a evolução da participação relativa dos escravos na população da Comarca no período. No final do XVIII essa participação se encontrava na faixa de $20 \%$, caindo sensivelmente até meados do século XIX, e de forma mais acentuada nas últimas décadas da escravidão. Note-se, portanto, que o percentual de cativos na população de toda essa região era relativamente baixo, quando comparado ao das áreas de plantation do Brasil colonial. ${ }^{43}$ Porém, tal como ocorria no Rio de Janeiro, também no Paraná havia diferenças regionais. Ao longo do período, no planalto o declínio da população escrava foi constante apenas para Curitiba e São José dos Pinhais, localidades certamente envolvidas com o tropeirismo, mas onde a agricultura de alimentos tinha, como já indiquei, grande destaque. Nas vilas de Castro e Santo Antonio da Lapa, mais "especializadas" na criação e nas invernadas, o montante de cativos, a despeito das oscilações, manteve-se relativamente estável, e isso apesar da baixa sensível, ao longo desse período, nos preços dos animais de transporte e de gado, devido à saturação dos mercados centrais, tornando o escravo mais caro para os pecuaristas (gráfico 1).

Gráfico 1: Variação \% de escravos na população de quatro localidades do Planalto paranaense (1782-1830)

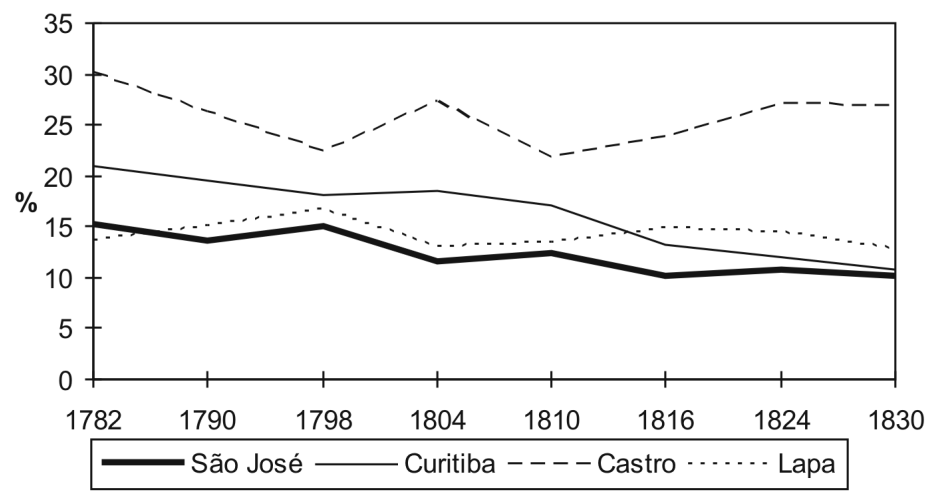

Fonte: Livro de Ordenanças de Curitiba de 1765, LNSJP, 1790. Cópias do acervo do CEDOPE-UFPR, originais no APESP. Para os demais anos, mapas da população São José dos Pinhais, Curitiba, Castro e Lapa, publicados em COSTA, Iraci del Nero \& GUTIÉRREZ, Horácio. Paraná. Mapas de População. 1798-1830. São Paulo: IPE/USP, 1985. Para 1790, os indices de Curitiba, Castro e Lapa são hipotéticos, calculados pela média dos anos de 1782 e 1798. 
Ao longo do todo o século XIX a população escrava do Paraná esteve sempre em situação de relativo equilíbrio no que respeita ao sexo. No conjunto da comarca, entre 1798 e 1830 o percentual médio de homens no grupo cativo foi calculado em $50,5 \%$, com poucas variações entre os anos pesquisados. Esse percentual era um pouco mais alto na região dos Campos Gerais (em Castro, por exemplo, a média foi calculada em 53,2\%) do que nas áreas de agricultura de abastecimento (em Curitiba a média era de $50,4 \%$ e em São José de 49,4\%). Gutiérrez creditou esse quadro de equilíbrio sexual a um crescimento natural positivo da população, hipótese que se reforça pelo fato de que, na passagem para o século XIX, a maior parte dos escravos da Comarca tinha nascido na região. ${ }^{44}$ Também a estrutura etária dos cativos tende a confirmar essa tese, pois existia certa semelhança entre os percentuais da população escrava e da população livre e mesmo da população branca. ${ }^{45}$

Horácio Gutiérrez também analisou a estrutura de posse de escravos no Paraná nas primeiras décadas do século XIX, encontrando nas listas nominativas de 1804 e 1824 a presença marcante de proprietários com 1 a 5 escravos (70 a 74\% dos senhores, nos respectivos anos). Além disso, este autor indicou a significativa desconcentração na posse dos cativos. Em 1824, por exemplo, a parcela majoritária dos pequenos senhores possuía cerca de $34,5 \%$ dos cativos, ao passo que os grandes proprietários (mais de 40 cativos) concentravam somente $5,3 \%$. Os senhores de grandes plantéis não chegaram ao patamar de $1 \%$ da amostra para ambos os anos pesquisados. ${ }^{46}$

\section{A cor dos escravos}

Salientei, anteriormente, a heterogeneidade original do grupo cativo do Paraná, formado por africanos, crioulos e índios de diversas naçôes. Dos dados das listas nominativas e dos mapas populacionais do Paraná no século XIX, creio poder afirmar que aquela heterogeneidade, antes tão marcante, estaria por então mais diluída. Nelas, a partir de 1798 os escravos eram discriminados especialmente pela cor (pardos ou negros).

Um exemplo está na lista nominativa dos habitantes da freguesia de São José dos Pinhais, de 1803, na qual foram registrados 255 cativos, dos quais de 249 pude ler a cor. Destes, 157 (63\%) foram identificados como pardos e 92 como negros. Sobre os cativos pardos nada mais constava, mas para os negros dava-se a informação de que quase todos eram crioulos, e apenas 16 escravos foram identificados como africanos, sendo cinco "da Costa", quatro da Guiné, quatro Angola, dois Mina e um "do gentio". Em 1827, dos 285 escravos registrados em São José, 119 (42\%) foram considerados pardos e 166 negros. Apenas oito desses últimos foram recenseados como africanos, sendo seis da Guiné e dois Benguela.

Os dados sobre a cor do conjunto da população paranaense, no período em que me detenho, fornecem outros indícios acerca da intensidade das relações entre aqueles povos de diferentes origens. $\mathrm{Na}$ tabela 2 apresento os índices percentuais relativos a cor de escravos e livres nos primeiros anos do Oitocentos. Por eles se pode perceber, em primeiro lugar, que em toda a região paranaense a população cativa apresentava um expressivo percentual de pardos, com uma média, ao longo do período, de 34,1\%. O mesmo ocorria entre os livres: em média, cerca de $28,8 \%$ deles eram pardos, enquanto apenas $2,3 \%$ eram negros.

Tabela 2 - \% de população de escravos e livres, por cor - Paraná (1798 - 1830)

\begin{tabular}{|c|c|c|c|c|c|c|c|c|}
\hline & 1798 & 1804 & 1810 & 1816 & 1824 & 1830 & MÉdIA \\
\hline \multicolumn{1}{|c|}{ POPULAÇÃO ESCRAVA } \\
\hline NEGROS & 69,4 & 64,8 & 58,2 & 69,7 & 70,4 & 63,1 & 65,9 \\
\hline PARDOS & 30,6 & 35,2 & 41,8 & 30,3 & 29,6 & 36,9 & 34,1 \\
\hline TOTAL & 100,0 & 100,0 & 100,0 & 100,0 & 100,0 & 100,0 & 100,0 \\
\hline \multicolumn{8}{|c|}{ POPULAÇÃO LIVRE } \\
\hline NEGROS & 2,0 & 2,4 & 2,7 & 2,5 & 2,5 & 1,8 & 2,3 \\
\hline PARDOS & 23,2 & 27,8 & 30,9 & 32,3 & 29,1 & 28,0 & 28,8 \\
\hline BRANCOS & 74,8 & 69,8 & 66,4 & 65,2 & 68,4 & 70,2 & 68,9 \\
\hline TOTAL & 100,0 & 100,0 & 100,0 & 100,0 & 100,0 & 100,0 & 100,0 \\
\hline
\end{tabular}

Fonte: COSTA, Iraci Del Nero \& GUTIÉRREZ, Horácio. Paraná. Mapas de População 1798-1830. São Paulo: IPE/USP, 1985, passim. 
Se aceitarmos que, no Brasil, a cor "reforçava" socialmente a condição de escravo, no Paraná isso era especialmente verdadeiro para aqueles tidos como negros. Isso porque boa parte da população livre do lugar tinha exatamente a cor (parda) como ponto em comum com cerca de $1 / 3$ da escravaria (os cativos pardos). Por um lado, isso pode sugerir que parte da população livre era vista "com um pé na escravidão", e/ou que parte da população escrava, aos olhos dos recenseadores, tinha "um pé no mundo dos livres". Afinal, como já se anotou,

as designaçôes de 'negro', 'cabra', 'pardo' e até mesmo a de 'criolo', embora não digam nada a respeito da condição social das pessoas assim nomeadas, mas sim de sua origem ou cor da pele, indicam a existência de outros níveis de diferenciação social que, para aqueles homens e mulheres coloniais, não eram subsumidos pelas distinções entre livres, forros e escravos. ${ }^{47}$

Para o caso dos escravos do Paraná (ou talvez para boa parte da região meridional do Brasil colônia), a partir de uma observação de Carlos Lima talvez se possa discutir um pouco mais este aspecto. $\mathrm{O}$ autor formulou a hipótese de que haveria uma hierarquia dos cativos, a que, tal como acontecia com os livres, estaria impressa na cor designada. Em um trabalho sobre a vila de Castro (nos Campos Gerais), nas primeiras décadas do século XIX, Lima analisou dados sobre as escravarias de duas fazendas. E o que de mais relevante percebeu foi a tendência de se identificar as mulheres como pardas e os velhos como negros. Para o autor, isso estaria sugerindo

que o tempo e as modificações do sistema escravista no Brasil do século XIX interferiam no processo de diferenciação dos escravos em pardos e negros. Mas não era só isso. Lugares possivelmente diferentes de homens e mulheres, assim como de jovens e de velhos nas relaçóes escravistas também tinham impactos na questão. ${ }^{48}$

De fato, nos dados sobre o conjunto dos cativos do Paraná, registrados nos mapas populacionais, também encontrei estas características. Em 1810, por exemplo, 45\% das cativas do Paraná foram recenseadas como pardas, sendo que em 1830 esse índice era de 38,5\%. Nesses mesmos anos, dos escravos do sexo masculino, $39 \%$ e $35,4 \%$, respectivamente, foram recenseados como pardos. Também encontrei uma relação entre cor e idade: em 1810, dos cativos com até dez anos, 55\% eram negros, eram dessa cor 59\% daqueles entre dez e 50 anos, e 65\% dos idosos; em 1830 esses percentuais eram, respectivamente, de 59\%, 64\% e 68\%. Na freguesia de São José dos Pinhais esta diferença era ainda mais visível. Em 1803, 69,7\% das escravas e 52,5\% dos escravos eram pardos; em 1827 estes índices eram, respectivamente, de $47,2 \%$ e $36,4 \%$. Da mesma forma, em 1803, dentre os cativos com até nove anos, $23,8 \%$ eram negros, daqueles entre dez e 49 anos, 39,4\% eram negros, e estes representavam 59,1\% dos cativos com mais de 50 anos. Em 1827 esses índices eram, respectivamente, de 47,3\%, 62\% e 72,7\%.

No entanto, seria o caso de perguntar por que, afinal de contas, o sexo e a idade de alguém seria fator condicionante da atribuição de sua cor? Creio que se pode ao menos aventar a hipótese de que, na região em estudo, tendia-se a identificar os nascidos no lugar como pardos (até porque muitos deveriam ter a pele mais clara, posto que descendentes também de indígenas e/ou de brancos), e como negros os cativos comprados no mercado externo ao vilarejo. E porque no grupo dos escravos nascidos nas localidades em que estavam estabelecidos quando recenseados certamente existia proporcionalmente mais mulheres e mais crianças, isso pode levar à ideia de que ser homem e ser idoso pudesse ser fonte de discriminação social.

Assim, se o tempo e as modificações do sistema escravista interferiam no processo de diferenciação dos escravos em pardos e negros, parece que esses fatores estariam contribuindo não tanto para a constituição de lugares possivelmente diferentes de homens e mulheres, assim como de jovens e de velhos nas relaçôes escravistas, mas principalmente para a distinção entre cativos "estrangeiros" e aqueles cujas origens os integrava à população local (livre e escrava) mesmo antes de nascer. ${ }^{49}$ 


\section{Pardos e negros livres na passagem do XVIII para o XIX}

Pelos dados da tabela 1, procurei salientar o expressivo contingente de livres de cor (em geral identificados como pardos) que compunha a população paranaense no período em fogo. E segundo os mapas de população, em 1798 os não brancos livres apresentavam um percentual um pouco mais alto de crianças, em relação aos brancos, e um índice inferior de idosos (mais de 50 anos). $\mathrm{O}$ mesmo quadro se apresentava em 1816, ainda que um pouco menos pronunciado. Em 1830 a estrutura etária dos dois grupos era muito semelhante. No que diz respeito ao sexo, para brancos ou não, nesse período essa era uma população com leve predomínio de mulheres, porém entre os não-brancos este predomínio era mais marcante.

Muitos desses muitos pardos livres certamente eram descendentes de indígenas ou mestiços de origem indígena e africana e/ou portuguesa. Todavia, é difícil estimar o peso desse grupo na população livre de cor, até porque quase nunca as fontes são claras sobre a questão. ${ }^{50}$ Outra parte da população de pardos e negros livres era, certamente, formada por libertos crioulos ou africanos, e seus descendentes, mestiços ou não. Em seu estudo sobre alforrias em Curitiba, Adriano Moraes Lima encontrou nos arquivos do $1^{\circ}$. cartório da cidade a ocorrência de 222 cartas de alforria para o período compreendido entre 1760 e $1830 .{ }^{51}$ No entanto, certamente muitos cativos foram alforriados apenas em testamento.

Outros libertos e livres de cor seriam migrantes, ou filhos e netos destes. Para a freguesia de São José dos Pinhais, por exemplo, as informações sobre naturalidade são mais sistemáticas na lista nominativa de 1803, e revelam a existência de fluxos migratórios de pardos vindos do sul (São Francisco e Ilha de Santa Catarina), do litoral e do planalto paranaense (Antonina e Paranaguá, Curitiba, Lapa e Castro), e por vezes de outras regiōes da capitania de São Paulo (Sorocaba, São Paulo, Mogi, Taubaté, Parnaíba, Lorena e Itu), de áreas mais longínquas da colônia (Rio de Janeiro e Minas Gerais). Carlos Lima, em estudo com informações sobre a vila de Castro, anotou que cerca de $24 \%$ dos livres de cor eram migrantes internos em 1816 e em $1835 .^{52}$ Pela lista nominativa de 1803, calculei que em São José dos Pinhais também em torno de $24 \%$ dos chefes de domicílios não brancos eram migrantes internos (sobre os agregados, infelizmente, as listas de São José não dão esta informação).

Tabela 3 - Posição domiciliar dos livres, por cor (\%). São José dos Pinhais - 1803 e 1827

\begin{tabular}{|c|c|c|c|}
\hline & BRANCOS & Não BRANCOS & TOTAL \\
\hline \multicolumn{4}{|c|}{1803} \\
\hline Chefe masculino & 15,7 & 12,9 & 14,1 \\
\hline Chefe feminino & 4,5 & 4,7 & 4,6 \\
\hline Esposa do chefe & 12,6 & 12,0 & 12,3 \\
\hline Filhos(as) & 54,9 & 52,8 & 53,8 \\
\hline Parente não nuclear & 9,3 & 10,7 & 10,1 \\
\hline Agregados(as) & 3,0 & 6,9 & 5,1 \\
\hline Total & 100,0 & 100,0 & 100,0 \\
\hline \multicolumn{4}{|c|}{1827} \\
\hline Chefe masculino & 17,5 & 14,8 & 16,2 \\
\hline Chefe feminino & 3,3 & 5,8 & 4,6 \\
\hline Esposa do chefe & 15,9 & 13,6 & 14,7 \\
\hline Filhos(as) & 59,4 & 53,9 & 56,6 \\
\hline Parentes não nuclear. & 2,5 & 5,9 & 4,2 \\
\hline Agregados(as) & 1,4 & 6,0 & 3,7 \\
\hline Total & 100,0 & 100,0 & 100,0 \\
\hline
\end{tabular}

Fonte: Listas nominativas de São José dos Pinhais, 1803 e 1827. Cópia CEDOPE/UFPR, originais no Arquivo de São Paulo. Em 1803 não foram computados 2 mulheres, cuja posição domiciliar não foi possivel determinar, e 41 expostos (30 brancos e 11 pardos)

Como viviam estes livres de cor? Tenho dados mais detalhados para São José dos Pinhais, freguesia que no período se caracterizava por uma economia de subsistência e abastecimento organizada basica- 
mente em pequenos sítios e com poucos escravos. Nessa área, e nesse período, parte substantiva dos pardos livres vivia com suas famílias, estabelecidos em domicílios autônomos mantidos basicamente com o trabalho familiar. Em 1803, viviam em São José dos Pinhais 1721 indivíduos livres, sendo 785 brancos e 936 não brancos. Em 1827, dentre os 2782 habitantes livres, 1379 eram brancos e 1403 identificados como não brancos. Pelos índices percentuais da tabela 3 é possível observar que os não-brancos apresentavam uma pequena desvantagem no que diz respeito à situação domiciliar, pois entre eles havia mais pessoas que viviam agregadas em casa de parentes ou de estranhos, e também um percentual maior de mulheres sozinhas chefiando domicílios.

Mas não era apenas essa a desvantagem. Os domicílios de não brancos em geral eram menores, pois os chefes de cor branca aparentemente tinham maior capacidade de incorporar parentes, agregados e escravos ao seu domínio. ${ }^{53}$ Por esta razão, também em geral os domicílios agrícolas chefiados por brancos eram menos produtivos: em 1803, dentre os fogos chefiados por brancos, 45,6\% produziram para o mercado e os demais apenas para o próprio sustento. Entre os chefiados por não brancos, esse índice foi calculado em apenas 22,5\%. Em 1818 o padrão se manteve, sendo o índice de $53 \%$ para os brancos e de $21,7 \%$ para não-brancos. ${ }^{54}$ Ademais, numa análise amostral eu inferi que a proporção de não brancos entre os proprietários era mais significativa quanto menor o tamanho da propriedade, e que somente no grupo dos proprietários de até dez alqueires de terras eles aparecem na proporção mais ou menos equivalente à sua participação na população livre. ${ }^{55}$

Para completar esse quadro, cabe aqui voltar à questão da agregação. Em um trabalho voltado exclusivamente para o tema, Eni Samara procurou definir a categoria "agregado". A partir de pesquisa sobre a vila de Itu, nas primeiras décadas do novecentos, a autora afirma tratar-se de uma sorte de homens, mulheres e crianças que tinham em comum o fato de não possuírem terras ou casa própria, tendo, portanto, que se ajustar aos proprietários das áreas rurais ou urbanas, dentro dos mais diferentes tipos de relaçôes. ${ }^{56}$

Por seu lado, Carlos Bacellar enfatiza que a agregação era um sintoma de uma sociedade onde alguns segmentos, por diversas razões, não encontravam condições de estabelecer-se autonomamente. Buscava-se, assim, trocar trabalho por teto e comida, ou instalar-se "de favor" em terras de outrem. Muitos agregados eram indivíduos solitários e extremamente pobres e desenraizados, mas também podiam ser chefes de família que detinham, inclusive, a posse de um ou dois escravos. Também variava o status do agregado no interior de um domicílio ou de uma propriedade: ele podia ser um idoso, um inválido ou uma mulher sozinha com filhos pequenos, podia ser um ex-escravo com parentes no plantel do chefe do fogo, ou mesmo um migrante recém-chegado à espera de oportunidade de ascensão social. Mas também podia ser o filho recém-casado, o irmão ou o pai do chefe do domicílio. ${ }^{57}$

Do que pude observar nas listas nominativas de São José dos Pinhais, tendo a confirmar a caracterização desses autores. De fato, nessa fonte aparecem três categorias de indivíduos livres agregados a algumas unidades formadas por famílias nucleares: parentes não nucleares, expostos e pessoas sem vínculos de parentesco com o chefe do fogo - estes, os que mais sistematicamente são identificados, nas listas nominativas de São José, pelo termo agregado e, portanto, assim serão referenciados daqui por diante.

Em 1782, cerca de 4\% da população livre de São José dos Pinhais era formada por indivíduos que viviam agregados em domicílio alheio; eram pouco mais de 5\% em 1803, e 3,7\% em 1827, lembrando que são anos em que o peso percentual da população cativa era de $13 \%$ e de $9,2 \%$, respectivamente. Esse contingente era marcadamente feminino: nos três anos observados $2 / 3$ deles eram mulheres, enquanto na população livre não agregada essa proporção ficou em torno de $1 / 2$. O grupo também era mais jovem: calculei a idade média dos agregados em 22,6 anos em 1782, em 19,7 anos em 1803 e em 17 anos em 1827. Já a idade média dos livres não agregados era de 24,2 anos em 1782, 20,8 anos em 1803 e 19,6 anos em 1827. Contudo, em relação à população livre não agregada, apenas em 1782 havia uma proporção maior de crianças entre os agregados. A principal característica desse grupo era o baixo peso percentual de idosos (especialmente em 1803). Além disso, como já indiquei, em São José dos Pinhais os agregados eram um grupo predominantemente não-branco: $74 \%$ deles eram pardos ou negros em 1803; índice que se ampliaria para 82\% em 1827. 
Nos três anos por mim observados, em São José dos Pinhais a imensa maioria dos fogos com agregados abrigava apenas um ou dois deles, e em nenhum havia mais do que sete. Embora existissem agregados em fogos escravistas, a agregação era mais comum naqueles sem cativos (estes constituíam $75 \%$ dos domicílios com agregados em 1782, quase 70\% em 1803 e 63\% em 1827), e a maior parte dos agregados encontrava-se neste tipo de domicílio (80\% em 1782, 64\% em 1803 e $61 \%$ em 1827).

Todavia, por esses mesmos números também se infere que, conforme se reduzia o contingente cativo na freguesia, mais os proprietários escravistas reuniam agregados. O que talvez se possa depreender destes dados é que, embora a prática da agregação não possa ser caracterizada exclusivamente como um sistema de arregimentação de mão-de-obra, para alguns escravistas, especialmente em conjunturas em que o acesso ao mercado de cativos se tornava proibitivo até mesmo àqueles com "maiores cabedais", esses indivíduos livres, quando agregados a seus domićlios, podiam se constituir em força de trabalho complementar.

Os dados referentes à Itu, estudados por Eni Samara, tendem a confirmar o que afirmei acima. Como já indicado, a autora observou esta vila na passagem do XVIII para o XIX, momento de expansão da economia açucareira. Ela percebeu que a larga penetração de mão-de-obra escrava relegava a segundo plano a mão-de-obra livre nas grandes fazendas, e que os agregados se concentravam mais nas propriedades de lavoura de mantimentos e nas unidades domiciliares da vila. Em 1798, em um bairro onde se localizavam grandes propriedades canavieiras, a pesquisadora não computou nenhum agregado e os escravos representavam $83 \%$ dos moradores, enquanto na rua do Ouvidor, no mesmo ano, $32 \%$ dos moradores eram agregados e menos de $11 \%$ escravos. Os índices que levantou para os demais bairros e ruas de Itu seguem praticamente o mesmo padrão. Por esta razão, Samara depreende que os agregados eram utilizados como mão-de-obra nas áreas de lavoura comercial somente em períodos de carência de escravos. Além disso, observou que, quanto mais crescia a população cativa na região, mais se reduzia a população agregada: entre 1785 e 1829 o percentual de escravos subiu paulatinamente de $25 \%$ até a casa de 55\%; já os agregados, que no início do período representavam em torno de $10 \%$ da população, chegam ao final do período a apenas $4 \% .^{58}$

Também os dados reunidos por Roberto Guedes Ferreira reforçam minha assertiva. A vila de Porto Feliz, vizinha à de Itu, no século XIX viu crescer significativamente sua população cativa, devido à expansão da economia canavieira. Entre 1798 e 1818 os escravos representavam entre 31 e 36\% da população total do lugar. Desde então este percentual subiu para 40\% em 1820 e 45\% em 1824, chegando a 51\% em 1829. Em movimento inverso, a proporção de agregados na população total, que girava em torno de $9 \%$ e 13\% entre 1798 e 1818, daí em diante caiu para 11,5\% em 1820 e 9,5\% em 1824, chegando em 1829 a apenas 5\%. Além disso, 36,5\% dos fogos registrados em 1820 tinham agregados; esse índice baixou para $30,6 \%$ em 1824, chegando a 19\% em 1829. Finalmente, em 1818 os domicílios escravistas que também agregavam livres representavam $12,5 \%$ do total de fogos da vila, e 38,5\% dos fogos escravistas; esses percentuais baixaram para $8 \%$ e $26 \%$, respectivamente, em 1829 . Do mesmo modo, $48,5 \%$ dos agregados de Porto Feliz estavam em fogos escravistas em 1798, e esse índice caiu para 45\% em 1829.59

De uma maneira geral, a historiografia indica que o agregado era visto, na sociedade colonial brasileira, como gente de menor "qualidade". Um exemplo pode ser encontrado em Vilhena. Ao descrever a população da Bahia, ele afirma que "a duração dos tempos tem feito sensível confusão entre nobres e abjetos plebeus". Entre suas observações consta que "há mesmo um ou outro que, não passando de um doméstico ou agregado à família de algum dos fidalgos, que têm vindo por governadores, quer ser o grão Tamerlão". ${ }^{60}$ Tratando da região paranaense, Octavio Ianni escreveu que ali a condição peculiar do agregado o colocava na situação de substituto e equivalente do escravo.

De um lado, ele não recebe salário em moeda, mas pagamento em espécie, segundo as condiçōes da economia doméstica e não de conformidade com um contrato tácito de obrigações mínimas. Por outro, ele isenta os seus 'senhores' dos trabalhos pesados, braçais, ou brutos, que na sociedade escravista são apanágio do cativo. Desta maneira, o agregado preenche funçôes do escravo. E isto se torna ainda mais significativo quando ele se encontra ligado a uma família de pardos livres, que deste modo se projetam econômica e socialmente como 'senhores. ${ }^{61}$ 
De todo modo, era melhor ser agregado do que ser escravo. Para citar apenas um exemplo extremo, Roberto Guedes Ferreira nos relata a história da fuga de alguns escravos na região de Porto Feliz, mais tarde encontrados vivendo sob a administração de um padre. Segundo o relato, eram tratados com "brandura e docilidade", a ponto de os cativos se conservarem "não como escravos, mas sim como agregados". ${ }^{62}$ Além disso, embora certamente muitos agregados estivessem condenados a viver nesta condição até a morte, para alguns era possível ascender a uma certa autonomia, constituindo domicílio em pequenas posses ou mesmo adquirindo um minifúndio.

Outros podiam ir ainda mais longe. Mais uma vez Roberto Guedes Ferreira nos fornece um exemplo disso. Ele abre sua tese de doutorado resumindo a trajetória de Jesuíno José da Rocha, nascido da união conjugal de Maria e Francisco, escravos do vigário de Porto Feliz entre 1803 e 1820, André da Rocha Abreu. Em 1803 o vigário alforriou o casal e seus filhos, e a família viveu agregada em sua casa até sua morte. Em vida, o padre André doou terras, engenho, escravos e um piano aos forros agregados, instituindo os filhos do casal como herdeiros. O piano foi dado a Jesuíno, que se tornou organista da vila ainda quando era agregado do padre, com quem o forro aprendeu a arte da música. Após a morte de André, o pardo Jesuíno José da Rocha passou a ser reconhecido com senhor de engenho. ${ }^{63}$

\section{Cor e status social no mundo dos livres}

Salientei que os agregados de São José eram principalmente pardos, e que estes eram em geral mulheres, crianças e jovens. Por essa razão é possível supor que a constituição e a reprodução da rede de dependência que envolvia e definia esse grupo não fosse, ali, tributária apenas da identificação senhorial do pardo e do negro com o cativeiro. Provavelmente elas relacionavam-se também com a composição sexo-etária dos livres de cor na freguesia naquele período: o alto percentual de mulheres e crianças nesse grupo (muitas delas filhos de homens cativos unidos a mulheres livres) deveria contribuir para a constituição de posições pouco privilegiadas, uma vez que geralmente determinava a necessidade da agregação.

O predomínio das atividades agrícolas na freguesia foi, talvez, outro fator decisivo para as desvantagens dos negros e pardos quando adentravam ao mundo dos livres, posto que, para o estabelecimento autônomo, se pressupunha a efetiva capacidade de ocupação de um pedaço de terra, o que nem sempre era possível. Mesmo os que puderam realizar tal empreendimento, provavelmente com muitas dificuldades puderam mantê-lo.

No entanto, os argumentos acima podem ser apenas parte da explicação para o predomínio de não brancos entre os agregados e entre os mais pobres dentre os chefes de domicílios de São José dos Pinhais. Uma outra hipótese poderia estar ligada à polêmica sobre designação da cor dos livres no Brasil escravista.

Em geral, como se viu, os historiadores concordam que, sob a escravidão, no Brasil a designação da cor das pessoas tinha mais relação com a sua inserção social do que propriamente com a ascendência étnica. Quando se refere à escravidão indígena na região paulista no século XVII, John Monteiro esteve atento à dimensão política da designação da origem. Ele comenta que embora no início dos apresamentos a maior parte dos cativos fosse do grupo Guarani (Carijós), os paulistas começaram a introduzir no cativeiro índios das mais diferentes etnias. Neste sentido, segundo o autor, a generalização do termo $c a-$ rijó pode refletir uma estratégia dos colonos na tentativa de padronizar uma população tão diferenciada, utilizando o modelo do cativo guarani. ${ }^{64}$

Hebe Mattos, por sua vez, observou que a categoria "pardo", típica do final do período colonial, tinha uma significação muito mais abrangente do que as de "mulato" ou "mestiço". Destaca também que em todo o período escravista os termos "negro" e "preto" foram usados exclusivamente para designar escravos e forros, e que "preto" era sinônimo de africano, sendo os índios escravizados chamados de negros da terra. A autora também esteve atenta à historicidade dessas categorias, quando escreveu que:

Pardo foi inicialmente utilizado para designar a cor mais clara de alguns escravos, especialmente sinalizando para a ascendência europeia de alguns deles, mas ampliou sua significação quando se teve que dar conta de 
uma crescente população para a qual não era mais cabível a classificação de 'preto' ou de 'crioulo', na medida em que estes tendiam a congelar socialmente a condição de escravo ou ex-escravo. A emergência de uma população livre de ascendência africana - não necessariamente mestiça, mas necessariamente dissociada, já por algumas geraçôes, da experiência mais direta do cativeiro - consolidou a categoria 'pardo livre' como condição linguística para expressar a nova realidade, sem que recaísse sobre ela o estigma da escravidão, mas também sem que se perdesse a memória dela e das restrições civis que implicava. Ou seja, a expressão 'pardo livre' sinalizará para a ascendência escrava africana, assim como a condição 'cristão novo' antes sinalizara para a ascendência judaica. Era, assim, condição de diferenciação em relação à população escrava e liberta, e também de discriminação em relação à população branca; era a própria expressão da mancha de sangue. ${ }^{65}$

O uso político de um termo para designar indivíduos e grupos com histórias e inserções distintas não é o único aspecto a se considerar. Em sua tese de doutoramento Roberto Guedes Ferreira procura explicar a frequente ocorrência de "mudança de cor" de um mesmo indivíduo, dependendo da fonte em que foi mencionado, e/ou ao longo de sua vida. Para esse autor, uma vez que - como assinalaram Hebe Mattos e outros - hierarquia e posição social estão manifestas na cor, a designação dessa última, seguindo as primeiras, também era fluida e dependia de circunstâncias sociais, sendo negociada e reatualizada. ${ }^{66}$

No que diz respeito às listas nominativas de Porto Feliz, com as quais trabalhou, Guedes reconheceu a existência de uma caracterização pontual e personalizada, determinando que as mesmas pessoas frequentemente mudassem de cor. Ele cita, por exemplo, que, em 1803, Alexandre de Madureira e sua esposa Inácia Maria eram negros, mas, em 1808, ambos foram identificados como pardos. O autor se pergunta se em 1803 eles seriam recém-saídos do cativeiro. Exemplo inverso é o de Antônio de Pontes e sua esposa Beatriz Maria, recenseados como mulatos em 1813, e negros em 1818. Roberto Guedes Ferreira não soube como explicar porque o casal "enegreceu”. Outro que mudou de cor em Porto Feliz, entre tantos casos, foi Antônio Gonçalves: em 1803, 1808 e 1813, ele e sua mulher, Constantina Maciel, eram pardos, mas, em 1818 , eram brancos. ${ }^{67}$

Também nas listas de São José dos Pinhais pude recolher exemplos destas mudanças. Esse foi o caso do lavrador Manoel Alves, registrado como branco, em 1803, na lista da terceira companhia de São José (casa 9). Naquela época ele estava casado com a parda Ana Ferraz (de 20 anos) e com eles viviam três filhos, todos recenseados como pardos. No domicílio estavam agregadas uma viúva e sua neta de cinco anos (brancas) e Manoel com seu escravo. Em 1810 ele, a esposa e quatro filhos aparecem como brancos na lista (casa 354). É identificado como lavrador, mas seu domicílio já não tem as agregadas e o escravo. Em 1817 Manoel estava "ausente para sul" e Anna e seis filhos ainda são brancos, mas por então foram identificados como pobres (casa 17, 3 ${ }^{\text {a }}$ cia). Em 1818 Manoel Alves novamente aparece como "ausente para o sul", dessa vez registrado como pardo, assim como sua mulher Anna e os seis filhos (casa 35, 33. cia). Em 1824 Manoel continua no sul e Anna Ferraz encabeça a listagem do fogo, vivendo com cinco filhos. Eles foram recenseados como pardos e pobres (casa 56, 3a . cia). Em 1827, finalmente, Manoel Alves está de volta e foi recenseado com a esposa e três filhos. Ele volta a ser identificado como lavrador e todos foram registrados como pardos (casa 13, $3^{\text {a }}$. cia). Talvez um caso em que o empobrecimento determina o descenso na hierarquia social, expresso na designação da cor?

Na lista nominativa de Paranaguá encontrei situação contrária, na casa de Manoel Lázaro, registrado como pardo em $1803 .{ }^{68}$ Ele era alfaiate e cabo de ordenança, e vivia com sua mãe Thereza Maria, viúva, também parda, e com Marianna, uma menina exposta branca. Na lista de 1813 esse alfaiate foi novamente registrado, agora como branco, e casado com a branca Maria Junqueira. Thereza Maria permanecia chefiando o domicílio e identificada como parda, embora não haja a alusão de que fosse a mãe de Manoel.

Também essa mudança é de difícil interpretação, pois inúmeras hipóteses podem ser levantadas, e nenhuma delas poderia ser comprovada: ele pode realmente ter omitido sua filiação para "passar por branco", ou talvez não fosse mesmo filho de Thereza Maria, sendo incorreta a informação fornecida pelo recenseador de 1803; pode ser também que em 1813, com base na cor da esposa, o recenseador tenha presumido a cor do marido, e assim por diante. Qualquer uma dessas hipóteses, contudo, nos indi- 
ca que deve estar correta uma outra inferência de Roberto Guedes Ferreira, a de que a designação da cor do individuo tendia a acompanhar a da família (nesse exemplo, o laço parental mencionado, primeiro com a mãe e depois com a esposa, foi o fator determinante para a designação da cor do indivíduo).

Além disso, a cor de alguém (e até sua condição jurídica) podia variar de acordo com o observador e o momento. $\mathrm{Na}$ verdade, os registros paroquiais que me permitiram recuperar as trajetórias de alguns casais de São José dos Pinhais parecem indicar que naquele meio as palavras tinham função política complexa, pois que visavam sacramentar laços de dominação e dependência: por exemplo, Gertrudes Leme, casada em 1783 com o escravo Antonio, ${ }^{69}$ era filha de um forro e uma administrada, conforme consta nos registros de batismo de suas irmãs. ${ }^{70}$ Após o casamento ela aparece agregada ao domicílio de Paulo da Rocha, senhor de seu marido, em várias listas nominativas, e nos registros de batismo dos sete filhos que teve com Antonio ${ }^{71}$ foi identificada, sucessivamente, como "administrada" de Paulo da Rocha, "parda forra", e por fim, como "forra".

Também foi o caso de Vicente Francisco, filho de administrados que após o casamento com a escrava Antonia ${ }^{72}$ torna-se agregado do proprietário de sua mulher e passa a ser identificado como forro, ou cabra forro. ${ }^{73}$ Anna Maria de Jesus, que se casou em 1780 com o escravo Laureano, ${ }^{74}$ nascera livre, pois segundo consta no registro do seu batismo, seus pais eram mulatos forros, ex-administrados de Jerônimo da Veiga. No entanto, a pobre Anna Maria acabou mulata forra, conforme foi anotado no registro de batismo de sua filha Joana, nascida em 1788 (livro 1, fls. 106).

Minhas pesquisas sobre casamentos no Paraná insinuam que também aqueles de mais "baixa esfera" eram ciosos de tais questōes. Um processo de 1750, em Paranaguá, envolveu Catarina Gonçalves (embargante), seu pai Domingos Gonçalves (denunciante) e Manoel Pereira, marinheiro (réu embargado). Nele o réu afirma que não podia se casar com Catarina Gonçalves por ser esta "bastarda e de baixa esfera e tem de branca pouco ou nada" ${ }^{75}$ Ao que parece, quando tratou o casamento com Catarina, Manoel Pereira considerava que a moça era suficientemente branca. Em algum momento, e por algum motivo, ele mudou de ideia.

Outro caso emblemático, nesse sentido, foi resgatado, mais uma vez, por Roberto Guedes Ferreira: Em julho de 1797, Tomás de Aquino havia feito uma solicitação para que seu próprio filho, Alexandre Garcia, fosse preso. O pedido foi aceito pelo governador e a captura efetuada pelo capitão-mor da vila. Porém, o capitão declarou que o requerimento era cheio de falsidade, acrescentando que,

requereu ele prisão e praça ao dito seu filho a fim de não efetuar-se o injusto e desigual casamento pretendido, quando este já há vinte e dois dias se achava efetuado, pois no dia 13 de junho próximo pretérito, pública e constantemente se receberam. [O pai] alegou também que estava tratado para casar com a filha de uma negra, quando é filha de Gabriel Antunes e de sua mulher, Maria Leite, pardos em grau remoto, que, sendo em qualidade de sangue, pouco ou nada diferentes do casal do Suplicante (...).Inculca-se o mesmo suplicante com estímulos de honra não convindo neste casamento por ignominioso (...) quando ele mesmo há tempos ajustou esse casamento, e ao depois (...) procurou desfazer o ajuste (...) me consta ao certo que o Suplicante variara daquele ajuste por induções de seu irmão, Agostinho Garcia, que procurava casar o dito Alexandre, seu sobrinho, com outra moça de seu empenho. ${ }^{76}$

Se aos olhos do capitão-mor a família de Gabriel Antunes era parda em grau remoto, aos de Tomás de Aquino eles eram negros. Porém somente depois que seu irmão arranjou um novo casamento para Alexandre (talvez mais conveniente) é que Tomás de Aquino passou a considerar como negra a família de Gabriel Antunes.

Enfim, as oscilações davam-se entre a cor negra e a parda, mas também entre a parda e a branca. E nesse último sentido deve-se atentar quando se analisam os dados sobre a cor das populaçóes das vilas paranaenses. De acordo com os dados dos mapas populacionais, para seis anos entre 1798 e 1830, o peso proporcional dos grupos de brancos e de pardos variou, no tempo, sempre no sentido inversamente proporcional, indicando mudanças na atribuição da cor de uma parcela de indivíduos, ora como brancos, ora como pardos. No mesmo período, a variação do percentual de negros tinha uma dinâmica independente (gráfico 2). Aliás, encontrei essas características igualmente em Curitiba (gráfico 3), em Pa- 
ranaguá (gráfico 4) - para citar as duas principais vilas da comarca no período - e mesmo no conjunto da população da freguesia de São José dos Pinhais (gráfico 5).

Gráfico 2 - \% de brancos, pardos e negros na população livre (Paraná, 1798-1830)

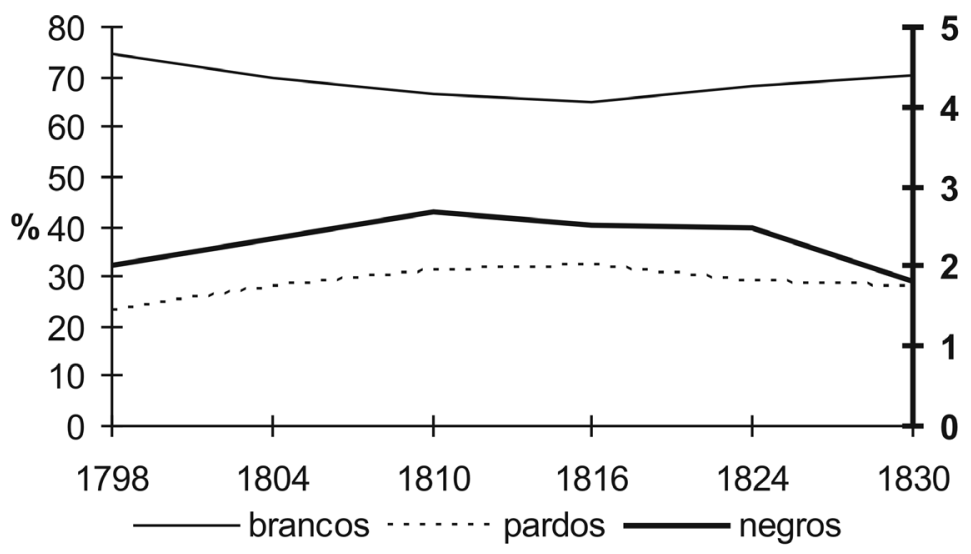

Fonte: COSTA, Iraci Del Nero \& GUTIÉRREZ, Horácio. Paraná. Mapas de População 1798-1830. São Paulo: IPE/USP, 1985, passim

Gráfico 3 - \% de brancos, pardos e negros na população livre (Curitiba, 1798-1830)

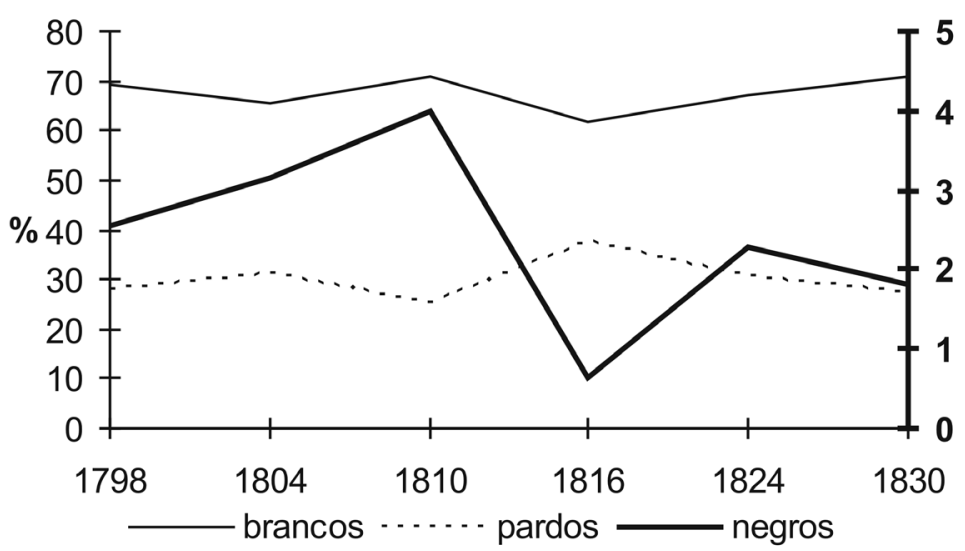

Fonte: COSTA, Iraci Del Nero \& GUTIÉRREZ, Horácio. Paraná. Mapas de População 1798-1830. São Paulo: IPE/USP, 1985, passim

Gráfico 4 - Variação \% de brancos, pardos e negros na população livre (Paranaguá, 1798-1830)

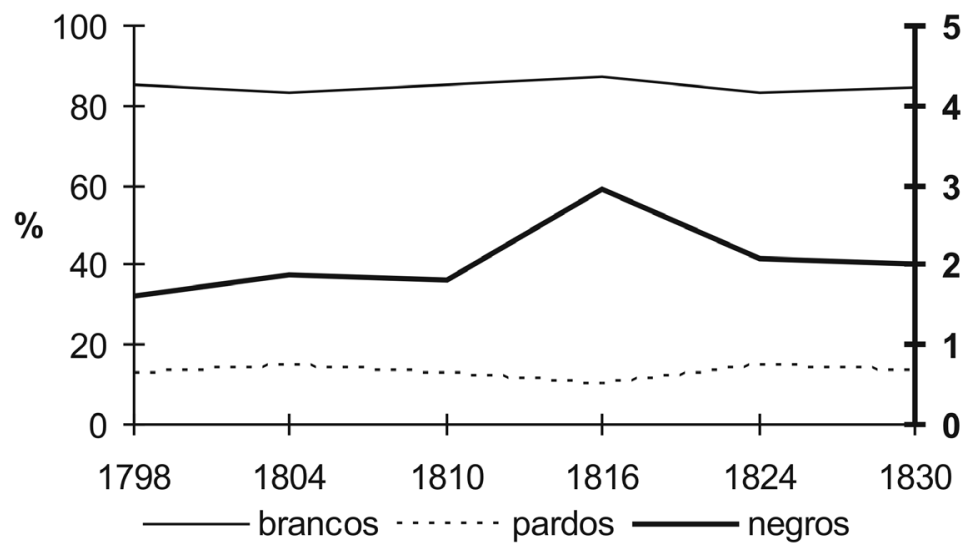

Fonte: COSTA, Iraci Del Nero \& GUTIÉRREZ, Horácio. Paraná. Mapas de População 1798-1830. São Paulo: IPE/USP, 1985, passim 
Gráfico 5 - Variação \% de brancos, pardos e negros na população livre (São José dos Pinhais, 1798-1830)

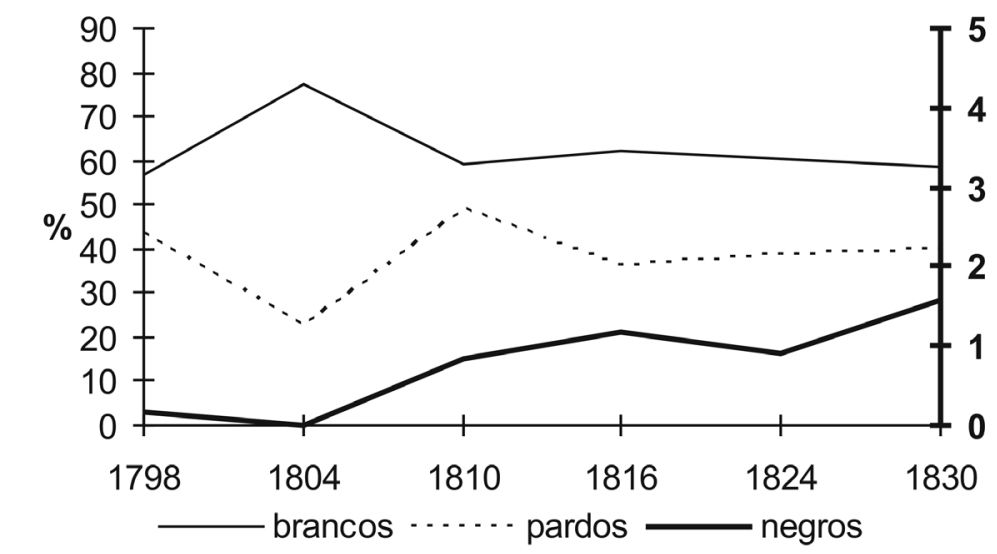

Fonte: COSTA, Iraci Del Nero \& GUTIÉRREZ, Horácio. Paraná. Mapas de População 1798-1830. São Paulo: IPE/USP, 1985, passim

Tal variação sugere que a designação da cor nos censos paulistas (as listas nominativas) e nos mapas populacionais dependia também de quem o preenchia, ou de quem fornecia as informações.

Além disso, há que se olhar com mais vagar a interessante hipótese de Carlos Lima, ao observar duas vilas do Paraná, também naquele período, uma menor e menos diferenciada socialmente (Guaratuba, do litoral) e outra maior e mais diferenciada (Curitiba, no planalto) - esta, com um significativo grupo de não brancos livres que eram proprietários de escravos. O autor partiu do princípio de que as diferentes aberturas para processos de acumulação nas duas vilas significavam brechas de tamanho também diverso para processos de mobilidade ascendente, inclusive de não-brancos. Isso se traduzia em mecanismos díspares de atribuição da cor às pessoas. Assim,

as possibilidades diferentes de ascensão social - embora dentro de limites modestos - levavam a que se enxergassem mestiços de maneiras diversas. No ambiente mais dinâmico de Curitiba, o espectro de atribuiçôes de cor se ampliava. Na estagnada Guaratuba, por outro lado, a situação era mais simples do ponto de vista social, com uma pobreza plana, pouco diferenciada internamente. Neste último caso, todos os que fossem livres não brancos eram vistos como pardos. ${ }^{77}$

Enfim, Lima acredita que o espectro de atribuições de cor da população se ampliava em ambientes escravistas economicamente mais dinâmicos. Quando se tratava de locus sociais pouco diferenciados internamente, haveria a tendência a perceber os livres não brancos de forma mais homogênea, sendo eles, em geral, identificados como pardos. Tendo a concordar com esse autor, mas acrescentaria que talvez a cor dos livres fosse avaliada também em função da maior ou menor presença de cativos no lugar.

Minha observação de que, naquela região, a cor negra era provavelmente atribuída a escravos recémchegados, e a cor parda aos ali nascidos e integrados socialmente, sugere que muitos escravos eram designados como pardos exatamente porque eram vistos como integrantes da comunidade de não-brancos (livres ou não) do lugar. Talvez tal percepção ocorresse também porque o grupo cativo era muito pequeno (e cada vez menor) na freguesia. Não por acaso, conforme se reduzia a presença de escravos, ao longo das primeiras décadas dos Oitocentos, crescia o peso percentual de pardos entre os agregados (74\% deles eram pardos ou negros em 1803; índice subiu para 82\% em 1827), certamente o grupo de livres socialmente mais próximo do grupo cativo.

Mas não apenas em ambientes de "escravidão rarefeita" esses critérios atuavam. Novamente recorrendo às pesquisas sobre Porto Feliz, efetuada por Roberto Guedes Ferreira, observei que naquela vila paulista, num período de incremento acelerado da população escrava, devido à expansão da economia canavieira, ocorreram alterações importantes na designação da cor dos agregados (tabela 4). 
Tabela 4 - Quantidade de agregados, de acordo à cor - Porto Feliz-SP (1798 e 1843)

\begin{tabular}{|c|c|c|c|c|c|c|c|c|}
\hline \multicolumn{4}{c}{ Branco } & \multicolumn{2}{c|}{ PARdo } & \multicolumn{2}{c|}{ Preto/NeGro } & \multicolumn{2}{c|}{ Total } \\
\hline ANo & $\#$ & $\%$ & $\#$ & $\%$ & $\#$ & $\%$ & $\#$ & $\%$ \\
\hline 1798 & 18 & 7,2 & 125 & 50,4 & 105 & 42,3 & 248 & 100,0 \\
\hline 1843 & 204 & 39,8 & 225 & 43,8 & 84 & 16,4 & 513 & 100,0 \\
\hline
\end{tabular}

Fonte: Banco de Dados de Roberto Guedes Ferreira, elaborado a partir das listas nominativas de habitantes de Porto Feliz, de 1798 e 1843.

Note-se, na tabela, que em 1798, quando ainda era pequena a população cativa da vila, quase todos os agregados foram identificados como pardos ou negros. Com a entrada maciça de escravos (quase todos africanos) uma grande parcela da população agregada marcou (ou teve marcado) seu afastamento em relação à comunidade dos escravos: muitos deixaram de ser negros, e um contingente ainda maior se tornou branco. Embora ao longo desse período Porto Feliz tenha recebido muitos migrantes, não há como explicar apenas por esse viés aquela tão brusca transformação na configuração da cor do grupo agregado.

\section{Conclusão}

\section{Russel-Wood já escreveu que}

em nenhum lugar como na América portuguesa a população desafiou tanto a classificação fenotípica somente por cor, cabelo, constituição física e características faciais e foram tão importantes a visão do outro, a visão de si mesmo, a postura e a "qualidade" - palavra que foge à definição mas que todo mundo entendia - para decidir qual o adjetivo ou expressão mais adequado para referir-se à cor do indivíduo. A cor da pele de alguém estava nos olhos do observador, mas o status social e econômico do observador e sua cor também desempenhavam seu papel em qualquer dessas atribuiçôes, assim como a época e a região. ${ }^{78}$

Ao longo desse artigo foram expostas inúmeras inferências no sentido de decifrar alguns aspectos desse enigma. Elas permitem admitir que, num plano geral, era a escravidão que orientava a designação social da cor dos livres e, portanto, a cor era também instrumento de construção social da hierarquia que os diferenciava. Relembro aqui o argumento de Hebe Mattos, de que a categoria "pardo livre" era condição linguística para expressar a emergência de uma população livre de ascendência africana, sem que recaísse sobre ela o estigma da escravidão, mas também sem que se perdesse a memória dela e das restriçôes civis que implicava. O caso paranaense, contudo, nos alerta que, ao menos nas regiōes onde a "administração" de ameríndios foi sistemática, por vezes avançando até princípios do Oitocentos, o passado de escravidão não estava associado apenas ao grupo de ascendência africana. Nos alerta, principalmente, que a categoria pardo também podia funcionar como marca de distinção mesmo no interior do grupo cativo, como se viu no caso dos escravos "do lugar" (pardos) e "estrangeiros" (negros).

As inferências expostas no artigo permitem admitir, igualmente, que no Brasil escravista a arbitrariedade quanto ao fenótipo obedecia a padrões sociais, tanto o que caracterizava o conjunto maior, quanto suas múltiplas expressões regionais. E a sugestão de Carlos Lima, de que o espectro de atribuiçôes de cor da população se ampliava em ambientes escravistas economicamente mais dinâmicos, é contundente nesse sentido. Os exemplos de Porto Feliz e do Paraná, por sua vez, nos permitiram observar a dinâmica dessa atribuição pois, conforme crescia ou decrescia o contingente escravo, os agregados "empardeciam" ou mesmo "embranqueciam", e vice-versa; nos permitiram observar também que a pobreza do domicílio "empardecia" as famílias, e que os signos de abastança (presença de escravos e/ou agregados) as "embranquecia".

Creio que os casos aqui tratados permitem, sobretudo, inferir que a arbitrariedade quanto ao fenótipo, em plena vigência da escravidão, era principalmente expressão da existência de relações políticas, por vezes conflituosas, que organizavam as relações pessoais e nas quais a cor era estratégica. Assim, como se viu, a família de Gabriel Antunes era parda quando Tomás de Aquino desejava casar seu filho 
com a filha daquele, porém tornou-se "negra" quando encontrou uma noiva mais conveniente. E o argumento da mancha de cor foi a base do requerimento que fez ao capitão-mor da vila. Do mesmo modo agiu Manoel Pereira, de Paranaguá, cuja noiva Catarina Gonçalves por alguma razão deixou de ser "branca" o suficiente para ser sua esposa. Como bem formulou Silvia Lara, "na América portuguesa na maioria das vezes as disputas se davam entre gente que não se distinguia "naturalmente" por sua nobreza (...). Talvez por isso precisassem ser tão ciosos dos qualificativos com que eram tratados". ${ }^{79}$

As mesmas relações políticas, desta vez marcadas pelo empenho em arregimentar dependentes, apareceram nos casos, por mim relatados, de indivíduos livres casados com escravos, como Gertrudes Leme, Vicente Francisco e Anna Maria de Jesus, todos os três nascidos livres e no entanto, após seus casamentos, foram recorrentemente identificados como mulatos, cabras e/ou pardos, termos sempre acompanhados das expressões "forro(a)" ou administrado(a).

As configurações dos gráficos 2, 3, 4 e 5 talvez sejam expressões estatísticas que resumem os resultados de uma gama infinita de relações, conflituosas ou não, que tornavam ainda mais subjetivas as designações da cor no Brasil escravista, mas que no entanto ajudaram a produzir e reproduzir a hierarquia social escravista mesmo em ambientes com poucos escravos.

\section{Notas}

${ }^{1}$ GLYCERIO, Carolina. Brasil tem a cara do futuro, diz professor. Reportagem da BBC Brasil, 28/05/2007.(http://www.bbc. co.uk/portuguese/reporterbbc/story/2007/05/printable/070528/_dna_brasilfuturo_cg.shtml).

${ }^{2}$ PENA, Sergio Danilo et alii. Retrato molecular do Brasil. Ciência Hoje, v. 27, no 159, p. 16-25, 2000.

${ }^{3}$ Depoimento do Professor Manolo Florentino (UFRJ), na mesma reportagem.

${ }^{4}$ SCOTT, Rebecca J. Exploring the meaning of freedom: post emancipation societies in comparative perspective. In: SCOTT, Rebecca J. et al (orgs). The abolition of slavery and the aftermath of emancipation in Brazil. Duke University Press, 1988, pp. 407-428.

${ }^{5}$ MERRICK, Thomas \& GRAHAM, Douglas. População e desenvolvimento econômico no Brasil de 1800 até a atualidade. São Paulo: Editora Jorge Zahar, 1981.

${ }^{6}$ MATTOS, Hebe; RIOS, Ana Lugão. Memórias do cativeiro: família, trabalho e cidadania no pós-abolição. Rio de Janeiro: Civilização Brasileira, 2005, p. 17.

${ }^{7}$ Idem, p. 21.

${ }^{8}$ Idem, pp. 28-29. Grifo meu.

${ }^{9}$ FREYRE, Gilberto. Sobrados e mucambos. Decadência do patriarcado rural e desenvolvimento do urbano. $4^{\mathrm{a}}$ ed., Rio de Janeiro: Livraria José Olympio Editora, 1968.

${ }^{10}$ LICCARDO, A; SOBANSKI, A; CHODUR, N.L. O Paraná na história da mineração no Brasil do século XVII. Boletim Paranaense de Geociências, nํ54, pp. 41-49, Curitiba: Editoria da UFPR, 2004, p. 46.

${ }^{11}$ WACHOWICZ, Ruy C. História do Paraná. 6a ed., Curitiba: Editora Gráfica Vicentina, 1988, p. 57.

${ }^{12}$ MARTINS, Romário. História do Paraná. Curitiba: Travessa dos Editores, 1995, p. 524.

${ }^{13}$ A seção meridional do Caminho do Viamão, isto é, de Curitiba aos campos do Rio Grande, é mais moderna que a de São Paulo a Curitiba. Primitivamente essa via de comunicação chegava a Curitiba passando por Campo Largo e São José dos Pinhais, mas com a abertura da estrada da Mata, do rio Negro para o Sul, as próprias tropas lhe foram dando curso mais direto, seguindo da Lapa ao rio do Registro. MARTINS, Romário. Op. cit., p. 524.

${ }^{14}$ Carta do ouvidor... Op. cit., p. 22.

${ }^{15}$ Idem, pp. 22-23.

${ }^{16}$ Nessas expedições participavam pequenos sitiantes e trabalhadores em busca de terras e oportunidades, mas chefiados predominantemente por criadores ou invernistas, ou seus prepostos, que estavam interessados em instalar-se em novas pastagens. In: IANNI, Octavio. Op. cit., p. 39.

${ }^{17}$ MACHADO, Brasil Pinheiro. Esboço de uma sinopse da história regional do Paraná. Revista História: Questōes \& Debates, ano 8, número 14, dezembro de 1987, (Escrito em 1951), p. 194.

${ }^{18}$ RITTER, Marina L. Op. cit., 1982, p. 43.

${ }^{19}$ Idem, p. 33. 
${ }^{20}$ MACHADO, Brasil Pinheiro. Formação da estrutura agrária tradicional nos Campos Gerais. Boletim da Universidade do Paraná, Departamento de História, no 3, junho de 1963, p. 12.

WESTPHALEN, Cecília Maria. Afinal, existiu ou não regime escravo no Paraná? Revista da SBPH, no 13: 25-63, 1997 , p. 47.

${ }^{21}$ Idem, ibidem.

${ }^{22}$ Saint-Hilaire, por exemplo, em 1820 registrou sua presença nas fazendas em que visitou. SAINT-HILAIRE, Auguste de. Viagem pela Comarca de Curitiba. Curitiba: Fundação Cultural, 1995.

${ }^{23}$ IANNI, Octavio. Op. cit., p. 48.

${ }^{24}$ RITTER, Marina. Op. cit., 1982, p. 33.

${ }^{25}$ Cf. Mapas econômicos de Paranaguá... A respeito do porto de Paranaguá cf. WESTPHALEN, Cecília Maria. O porto de Paranaguá e as flutuaçôes da economia ocidental no século XIX. Boletim do Departamento de História da UFPR, $20,1973$. Em fins do século XVIII Paranaguá também servia de ponto de comércio de mercadoria da Europa e do nordeste do Brasil com destino ao Rio da Prata.

${ }^{26}$ BALHANA, Altiva. Op. cit., 1972, pp. 5-26.

${ }^{27}$ GÓES, José Roberto. O cativeiro imperfeito: um estudo sobre a escravidão no Rio de Janeiro da primeira metade do século XIX. Vitória: Lineart, 1993, pp. 35-40.

${ }^{28}$ MONTEIRO, John Manuel. Negros da Terra. Indios e bandeirantes nas origens de São Paulo. São Paulo: Companhia das Letras, 1994.

${ }^{29}$ Idem, p. 8.

${ }^{30}$ Idem, ibidem.

${ }^{31}$ Idem, p. 18.

${ }^{32}$ Idem, ibidem.

${ }^{33}$ Idem, p. 137.

${ }^{34}$ Provimentos do Ouvidor Pardinho para Curitiba e Paranaguá (1721). Revista Monumenta, vol. 3, no 10, Curitiba: Aos Quatro Ventos, Inverno de 2000.

${ }^{35}$ IANNI, Octavio. Op. cit., p. 125.

36 SCHWARTZ, Stuart. Escravos, roceiros e rebeldes. Bauru: Edusc, 2001, p. 218.

${ }^{37}$ WESTPHALEN, Cecília Maria. A introdução de escravos novos no litoral paranaense. Revista de História. São Paulo, Universidade de São Paulo, 44(89): 139-154, jan./mar. 1972 e GUTIÉRREZ, Horácio. Crioulos e africanos no Paraná, 1798-1830. Revista Brasileira de História. V. 8, no 16, março-agosto/1988.

38 Processos de Auto de contas, 1727, cópias do Centro de Documentação e Pesquisa da História nos Domínios Portugueses/Departamento de História/Universidade Federal do Paraná, originais no Arquivo Dom Leopoldo Duarte. Cúria Metropolitana de São Paulo.

${ }^{39}$ GOLDSCHMIDT, Eliana Maria Réa. Casamentos mistos de escravos em São Paulo colonial. Dissertação de mestrado, FFLCH-USP, São Paulo, 1986, p. 20.

${ }^{40}$ IANNI, Octavio. Op. Cit., p. 40.

${ }^{41}$ Idem, p. 125.

${ }^{42}$ Idem, p. 70.

${ }^{43} \mathrm{Na}$ capitania do Rio de Janeiro, por exemplo, metade da população era formada por cativos em 1789 . No início da década de 1820, esse contingente baixou sua representação para um terço, embora na área rural os escravos continuassem compondo a metade da população. FLORENTINO, Manolo; GÓES, José Roberto. A paz nas senzalas: famílias escravas e tráfico Atlântico, Rio de Janeiro, c. 1790, c. 1850. Rio de Janeiro: Civilização Brasileira, 1997, p. 45.

${ }^{44}$ GUTIÉRREZ, Horácio. Demografia escrava numa economia não-exportadora: Paraná, 1800-1830. Estudos Econômicos, São Paulo, 17 (2): 297-314, maio/ago. 1987, pp. 298-300.

GUTIÉRREZ, Horácio. 1988. Op. cit., pp. 168-173.

${ }^{45}$ COSTA, Iraci Del Nero; GUTIÉRREZ, Horácio. Op. cit. 1985, passim.

${ }^{46}$ GUTIÉRREZ, Horácio. citado por PENA, Eduarto Spiller. O jogo da face. A astúcia escrava frente aos senhores e à lei na Curitiba provincial. Curitiba: Aos Quatro Ventos, 1999, p. 29.

${ }^{47}$ LARA, Silvia Hunold. Campos da violência: escravos e senhores na capitania do Rio de Janeiro, 1750-1808. Rio de Janeiro: Paz e Terra, 1988, p. 350.

${ }^{48}$ LIMA, Carlos A. M. Um pai amoroso os espera: sobre mestiçagem e hibridismo nas Américas Ibéricas. In: GEBRAN, Philomena et al. Desigualdades. $1^{a}$ ed. Rio de Janeiro, 2003, v. 1, p. 71. 
${ }^{49}$ Cruzando as informações da lista de 1803 com uma listagem de registros de batismos e de casamentos da paróquia do Patrocínio de São José dos Pinhais, pude levantar alguns laços de parentesco. Embora não seja uma observação conclusiva, encontrei uma forte tendência, nos casos de mães solteiras pardas, em se identificar seus filhos pela mesma cor; e no caso das mães solteiras negras, alguns dos filhos eram registrados como negros e outros como pardos. Dos poucos casais que pude identificar, encontrei a mesma tendência: um casal pardo teve seus filhos listados como pardos, um casal negro e dois casais mistos (negro com parda) tiveram parte dos filhos identificados como negros e outra parte como pardos.

${ }^{50}$ Sérgio Nadalin, por exemplo, cita o caso de Gregório Gonçalves e sua mulher Anna Maria de Lima, cuja ata de casamento, em 1772, na Igreja Matriz de Nossa Senhora da luz dos Pinhais (Curitiba), identifica Anna como mulata forra, mas é omissa quanto à origem de Gregório. $\mathrm{O}$ autor aponta possibilidade de ser ele um mestiço, provavelmente filho de um mameluco com indígena, como sugere sua descrição física: "Gregório Gonsalves Fernz [Fernandez]... estatura baixa cara comprida trigreiro cabelo pretto e corredio.” (NADALIN, S. O. A população no passado colonial brasileiro: mobilidade versus estabilidade. Revista Topoi, Rio de Janeiro, v. 4, nº 7, 2003, pp. 229-267). Um outro exemplo dessa imprecisão, agora nas listas nominativas de São José dos Pinhais, é o de Jerônimo Teixeira, recenseado como pardo em 1782, como "oriundo da terra” em 1790, e como mulato em 1798.

${ }^{51}$ LIMA, Adriano Morais. Trajetórias de crioulos: um estudo das relaçôes comunitárias de escravos e forros no termo da Vila de Curitiba (c. 1760 - c. 1830). Dissertação de mestrado, Curitiba: PPGHIS-UFPR, 2001.

${ }^{52}$ LIMA, Carlos A.M. Sertanejos e pessoas republicanas: livres de cor em Castro e Guaratuba (1801-1835). Estudos afro-asiáticos, 2002, ano vol. 24, no 2, pp. 317-344.

53 Segundo dados das listas nominativas de São José dos Pinhais, em 1803, havia ao menos um escravo em 40\% dos domicílios de chefia branca, ao menos um agregado em $27 \%$ deles, e ao menos um parente em 26\%. No mesmo ano não havia escravos em nenhum dos domicílios chefiados por não brancos, e os percentuais de agregados e parentes eram, respectivamente, de $11 \%$ e 23\%. Em 1827 esses percentuais eram de 31\%, 27\% e 26\% em domicílios chefiados por brancos, e de 0,7\%,7\% e 13\% nos domicílios chefiados por não brancos.

${ }^{54}$ Listas nominativas de São José dos Pinhais, 1803 e 1818. Acervo CEDOPE/UFPR, originais no Arquivo do Estado de São Paulo.

55 O cruzamento das informações do Inventário de Bens Rústicos de 1818 com aquelas presentes na lista nominativa de São José dos Pinhais, do mesmo ano, me permitiu essa avaliação da relação entre a cor e a propriedade de terras. Do cruzamento obtive uma amostra de 90 proprietários que detinham 95 das 205 propriedades registradas no Inventário (portanto 46\% delas) e a cerca de $40 \%$ das terras ocupadas na freguesia. Desses 90 proprietários, 70 aparecem recenseados como brancos na lista nominativa de 1818, 19 como pardos e apenas um como negro. Os 20 proprietários não brancos, juntos, detinham apenas 3,6\% da área de terras da amostragem (num ano em que os pardos e negros eram 42,5\% da população livre da freguesia), e suas propriedades eram quase sempre minúsculas.

${ }^{56}$ SAMARA, Eni de Mesquita. O papel do agregado na região de Itu. 1780 a 1830. Coleção Museu Paulista, série História, vol. 6, São Paulo: Museu Paulista, 1977, p. 42.

${ }^{57}$ BACELLAR, Carlos. Agregados em casa, agregados na roça: uma discussão In: SILVA. Maria Beatriz Nizza da (org). Sexualidade, família e religião na colonização do brasil. Lisboa: Livros Horizonte, 2001, p. 187-199.

58 SAMARA. Op. cit., pp. 43-47 e 73-74.

${ }^{59}$ Esses dados me foram generosamente cedidos por Roberto Guedes Ferreira, retirados de um banco de dados por ele criado para a confecção de tese de doutoramento.

${ }^{60}$ VILHENA, Luiz dos Santos. Recopilação de notícias soteropolitanas e brasílicas contidas em XX cartas [1802] Bahia, Imprensa Oficial do Estado, 1921, pp. 44-45. Apud: LARA, Silvia Hunold. Fragmentos setecentistas: escravidão, cultura e poder na América portuguesa. Tese de Livre Docência. Campinas: UNICAMP, 2004, pp. 186-187.

${ }^{61}$ IANNI, Octavio. Op. cit., pp. 74-75.

${ }^{62}$ FERREIRA, Roberto Guedes. Op. cit., p. 101.

${ }^{63}$ Idem, introdução.

${ }^{64}$ MONTEIRO, John Manuel. Op, cit., pp. 165-166.

${ }^{65}$ MATTOS, Hebe. Escravidão e cidadania no Brasil monárquico. Rio de Janeiro: Jorge Zahar, 2000, pp. 6-18.

${ }^{66}$ FERREIRA, Roberto Guedes. Op. cit., p. 101.

${ }^{67}$ Idem, pp. 93-108.

${ }^{68}$ Lista Nominativa de Paranaguá, 1803, 3aㅡ Cia, casa 4.

${ }^{69}$ Livro 1 de Casamentos da Paróquia de São José dos Pinhais, fl. 75. Arquivo da Paróquia de São José dos Pinhais, Pr.

${ }^{70}$ Izabel foi batizada em novembro de 1755 (Livro 1 de Batismos de São José dos Pinhais, fl. 83) e Maria, em 1774 (Livro 1 da mesma paróquia, fls. 106v/ 107). Arquivo da Paróquia de São José dos Pinhais, Pr. 
${ }^{71}$ Francisco, nascido em 1784 (Livro 1 de Batismos, fl. 99), Leonor, em 1789 (Livro 1, fl. 106v), Maria, em 1792 (Livro 1, fl. 115V). Izabel, em 1793 (Livro 1, fl. 120v), Joaquim, em 1795 (Livro 1, fl. 130); Manoel, em 1797 (Livro 1, fl. 133) e João, em 1800, (Livro 1, fl. 138v). Arquivo da Paróquia de São José dos Pinhais, PR.

${ }^{72}$ Livro 1 de casamentos de São José dos Pinhais, fl. 53v. Arquivo da Paróquia de São José dos Pinhais, Pr.

${ }^{73}$ Citado como forro nos registros de batismo de seus três filhos: Antonio, em 1777 (Livro 1, fls. 88v), Rita, em 1780 (livro 1, fls. 92v) e Anna, em 1788 (livro 1, 105v). Arquivo da Paróquia de São José dos Pinhais, PR. Citado como cabra forro no Autos de Livramento, 1785, Ouvidoria geral de Paranaguá, 26p., JP1433 CX 69, Arquivo Público do Paraná

${ }^{74}$ Livro 1 de casamentos de São José dos Pinhais, fls. 85. Arquivo da Paróquia de São José dos Pinhais, PR.

${ }^{75}$ Autos de petição de caução. 1750. 40 p. Série Esponsais / Século XVIII (1720-1750), microfilme rolo 6, do acervo do CEDOPE. Original no Arquivo da Cúria Metropolitana de São Paulo.

${ }^{76}$ FERREIRA, Roberto G. Op. cit., p. 89.

${ }^{77}$ LIMA, Carlos A.Medeiros de. Op. cit. 2003, pp. 71-72.

${ }^{78}$ RUSSEL-WOOD, A J. R. Escravos e libertos no Brasil colonial. Rio de Janeiro: Civilização Brasileira, 2005, p. 297.

${ }^{79}$ LARA, Silvia H. Op. cit., 2004, p. 153.

\section{RESUMO}

Em geral os historiadores concordam que, sob a escravidão, a designação da cor das pessoas no Brasil tinha mais relação com a sua inserção social do que propriamente com a ascendência étnica. Nesse sentido, nesse artigo exponho alguns aspectos acerca do processo de diferenciação social, por meio da designação da cor, no interior do grupo de escravos e pobres livres que viviam no Paraná na passagem do XVIII para o XIX, uma região com poucos escravos e com predominio de pequenas escravarias e de domicílios não escravistas de brancos e pardos pobres.

Palavras-chave: escravidão; hierarquia social; cor.

\section{ABSTRACT}

Historians generally agree that, under slavery, the designation of colour of people, in Brazil, had more relation with social insertion than ethinic ascendence. Therefore, in this article I expose many aspects of process of social diferenciation through designation of colour, in a group of slaves and poor free that lived in Parana from the late eighteenth to early nineteenth, region with a small slave population, predominance of owners with few slaves and househoods of white and pardos poors without slaves.

Keywords: slavery, social hierarchy, colour. 